Research, part of a Special Feature on Landscape Scenarios and Multifunctionality - Making Land Use Assessment Operational

\title{
Global Impacts of European Agricultural and Biofuel Policies
}

\author{
$\underline{\text { Anne Gerdien Prins }}^{1}, \underline{\text { Bas Eickhout }}^{1,2}, \underline{\text { Martin Banse }}^{3,4}{ }^{\text {Hans van Meijl }}{ }^{3}$, Willem Rienks ${ }^{5}$, and \\ Geert Woltjer $^{3}$
}

\begin{abstract}
Food supply and food distribution have been and are important issues in the global political arena. The recent emergence of biofuel policies has increased the influence of the policy arena on agricultural production. In this paper we show the regional impact of changes in the European Common Agricultural Policy and biofuel policy. Shifting trade patterns, changes in agricultural production, and expansion of agricultural area or intensification of agriculture result in changes in land use and land use emissions. Higher prices for agricultural crops on the world market together with changing production raise agricultural income. Brazil is the region the most affected. The results show that arrangements or policies will be needed to avoid negative impacts in other regions of changing agricultural or biofuel policies in the European Union.
\end{abstract}

Key Words: agricultural income; biodiversity; biofuels; CAP reform; land use

\section{INTRODUCTION}

Food supply and food distribution have been and are important issues in the global political arena. Policies to ensure food supply or restrict food production have been in practice since the beginning of the $20^{\text {th }}$ century. These policies have been heavily discussed, not in the last place for their impacts on trade and the environment. In this paper, we show the impact of changes in (European) agriculturalrelated policies on countries or country blocks outside the European Union (EU). The policies concerned are the European Common Agricultural Policy, the global abolishment of agricultural subsidies and trade barriers, and the European proposal for renewable energy.

In 2008, the global agricultural system gained a lot of attention due to rising food prices and the political discussion around biofuels. A growth in population and increase in welfare will further create pressure on the food market in the coming decades (Hanemaaijer et al. 2008, Nellemann et al. 2009). Another important trend is the increasing linkages between different agricultural commodity markets and between the agricultural commodity markets and the fossil fuel markets (FAO 2008). The link between the agricultural market and the fossil fuel market is enforced by policies that stimulate the use of biomass, especially food crops, for energy. Policies can influence the way the extra food, feed, or fuel will be produced, for example by land use or land management policies, technological transition, or trade with other regions. These policies, together with historical and environmental conditions, will ultimately define the pressure on natural habitats and the way of managing agricultural areas in the different regions of the world.

The increasing demand for food, feed, and fuel not only puts additional pressure on the food market, it results in increasing pressure on natural habitats and ecosystem services. The increase in provisioning services in some cases directly results in a decrease in regulating, cultural, and supporting services that ecosystems provide (Millennium Ecosystem Assessment 2005). In other cases, the decrease in regulating, cultural, and supporting services is a direct result of the entire transformation of ecosystems or habitats. For example, the conversion of natural areas to produce biofuels greatly decreases carbon storage capacity. The impact of land use changes on water regulating services, like 
evapotranspiration and water retention, are other examples (Douglas et al. 2005).

Clearly, the European Union, as an important player in several agricultural commodity markets, with its Common Agricultural Policies (CAP) and proposals for energy policies (EC 2008), plays a pivotal role in the current debate on agriculture and food prices. However, the discussions on impacts of European policies are usually restricted to the European level (Nowicki et al. 2006). Global trade liberalization studies usually focus on impacts of full trade liberalization in all regions, and hardly distinguish impacts of regional policies or address environmental issues (Van Meijl and Van Tongeren 2002, Francois et al. 2005, Hertel and Keeney 2006). When environmental impacts are addressed, no specific attention is given to the impact of European policies (Eickhout et al. 2007).

This paper focuses on the impacts of European agricultural and biofuel policies on agri-economic and environmental indicators in regions outside the EU. For this analysis, we use a global modeling framework that links economic and environmental models. This framework has been developed in the context of the Eururalis project (Van Meijl et al. 2006, Eickhout et al. 2008b). Although the core of the Eururalis modeling framework lies within Europe (Verburg et al. 2008), the project explicitly aims at providing insights into the EU in the context of the rest of the world (Westhoek et al. 2006, Banse et al. 2008). The second version of the Eururalis modeling framework was released recently (Eickhout and Prins 2008, Rienks 2008).

\section{METHODS}

\section{Modeling framework}

The Eururalis modeling framework links three models (Klijn et al. 2005, Eickhout and Prins 2008, Rienks et al. 2008, Verburg et al. 2008): LEITAP, IMAGE, and CLUE-s. In this way, social-economic indicators and biophysical indicators can be taken into account in the analysis. Additionally, different scales from the global level to the $\mathrm{km}^{2}$-level within the European Union are linked.

LEITAP, based at the Agricultural Economics Research Institute (LEI), is a general equilibrium model at world level. It assesses demand, supply, and trade of agricultural products, industry, and services based on expected economic growth (GDP), demographic developments, technological developments, and policy changes. Based on the standard GTAP model (Hertel 1997), LEITAP has especially been extended in the agricultural sector (Van Meijl et al. 2006). Land-supply curves have been implemented in LEITAP, and take into account limited land availability and land heterogeneity (Eickhout et al. 2008b). In addition to its use in the agricultural sector, LEITAP has been used to assess production, trade, and consumption related to industry and services. The petroleum sector of LEITAP has been extended to enable the use of agricultural products like wheat, maize, and sugar as intermediate inputs (Woltjer et al. 2007). This feature allows biofuel policies to be assessed by accounting for impacts on land use, environment, and other food-related products.

IMAGE, based at the Netherlands Environmental Assessment Agency (MNP, formerly RIVM), is an Integrated Assessment Model. It was originally set up to analyze climate change (Rotmans 1990). Land use change plays an important role, and was incorporated in an early stage (Alcamo 1994, Alcamo et al. 1999, IMAGE Team 2001, MNP 2006). Within the Eururalis framework, IMAGE has been used to analyze the impact of the policy options on biophysical processes. This includes the impact of economic results of the policy options as calculated by LEITAP (for example, agricultural production) on biophysical processes (for example, land use change and related emissions). IMAGE simulates the land use system at a global grid level ( 0.5 by 0.5 degrees), leading to land-specific $\mathrm{CO}_{2}$ emissions and sequestration, and other land-related emissions, like $\mathrm{CH}_{4}$ from animals and $\mathrm{N}_{2} \mathrm{O}$ from fertilizer use (MNP 2006). Feedbacks of $\mathrm{CO}_{2}$ concentrations and climate change on the agricultural sector and natural biomes are modeled within IMAGE (Leemans et al. 2002).

CLUE-s, based at Wageningen University (WUR), is a spatially explicit land use dynamics model. Within the Eururalis project, this model covers the biophysical indicators in the countries within the European Union (Verburg et al. 2002, Verburg et al. 2004). CLUE-s simulates land use change at a high spatial resolution within Europe, taking into account spatial and environmental policies. Land requirements and location suitabilities define the competitive capacity of different land use types at a specific location. Additionally, specific characteristics of land use types that influence 
conversion are taken into account, e.g., a specification of plausible conversions (Verburg et al. 2002, Verburg et al. 2008).

LEITAP and IMAGE are linked to each other through agricultural production and changes in productivity due to management, climate change, and allocation (Fig. 1). Growth in agricultural productivity due to research and development is taken into account as an exogenous factor based on projections that were elaborated in the FAO publication World Agriculture towards 2015/2030 (Bruinsma 2003). Change in agricultural production is calculated by LEITAP, and results have been used by IMAGE instead of its Agricultural Demand Module (MNP 2006). Within LEITAP, a nested structure for agricultural factor inputs has been used. This allows the model to substitute land, labor, and capital with each other in order to produce demand. The land market is explicitly modeled by using a land supply curve in LEITAP (Fig. 2) in order to express the finiteness and heterogeneity of this factor. The land supply curve is based on grid cell information of IMAGE and describes the amount of land available for agricultural expansion in a region, and its price. The price is derived from the potential productivity in the specific grid cells of a region. The marginal costs of expanding agriculture in land-scarce countries (like China) are higher than in land-abundant countries like Canada (Eickhout et al. 2006). LEITAP can shift towards the use of more capital and labor for agricultural production instead of land. The use of capital and labor is expressed by the management factor. This factor is fed into IMAGE, adapting the exogenous management factor of each region and each agricultural activity to their developments in LEITAP.

IMAGE allocates the agricultural land needed according to the production and productivity change in each region in LEITAP and takes into account the actual productivity of each grid cell. Due to expansion of agricultural area, average crop yields in each region change. The correction of average yields and changes in yields due to climate change are fed back to LEITAP.

Afterwards, changes in agricultural area at the level of individual European countries are used by CLUE-s to allocate land use in Europe. Since the analysis in this paper shows the impacts of European policies on the rest of the world, only results of LEITAP and IMAGE have been used for this article.
Therefore, the energy sector in LEITAP has been extended based on the GTAP-E approach (Burniaux and Truong 2002). The GTAP-E model aggregates all energy-related inputs for the petrol sector, like gas and oil, in a nested structure on the value added side. These energy inputs can be substituted or complemented with capital, ending in a capitalenergy composite at the highest level (Fig. 3, left panel). In order to implement the biofuels, the nested structure of non-coal products in LEITAP has been split into fuel and gas. The fuel aggregate consists of vegetable oil, oil, petroleum products, and ethanol (Fig. 3, right panel), in which ethanol is an aggregate of sugar-beet/cane and cereals. Second generation biofuel crops (or woody biofuel crops) are not taken into account in this analysis. The nested Constant Elasticity of Substitution structure implies that necessary variables of the demand for biofuels are the relative price developments of crude oil versus the development of agricultural prices. Also important is the initial share of biofuels in the production of fuel. A higher share implies a lower elasticity and a larger impact on the oil markets. Finally, the values of the various substitution elasticities $\left(\sigma_{\text {Fuel }}\right.$ and $\left.\sigma_{\text {Ethanol }}\right)$ are crucial. These represent the degree of substitutability between crude oil and biofuel crops. The values of the elasticity of substitution are taken from Birur et al. (2008). The mandatory blending target of the EU directive has been implemented by giving a subsidy to the petrol industry, which lowers the costs of biofuel products. This is modeled as an endogenous variable which varies between EU countries. To make this a budget neutral subsidy, it is counterfinanced by an end-user tax on petrol consumption (Woltjer et al. 2007).

\section{Scenarios}

The scenarios calculated were built on the scenario approach of the Eururalis project (Westhoek et al. 2006, Eickhout and Prins 2008) (Table 1). The Baseline scenario for this article was derived from the Global Economy scenario, and all assumptions about GDP, population, and productivity growth remained unchanged. Assumptions about policy changes deviated from policy changes of the Global Economy scenario. The Global Economy scenario is an elaboration of one of the four emission scenarios of the Intergovernmental Panel on Climate Change, as published in its Special Report on Emission Scenarios (Nakicenovic 2000). In the Baseline scenario, all agricultural policies were kept 
Fig. 1. Methodology of model interaction between LEITAP and IMAGE (source MNP 2006).

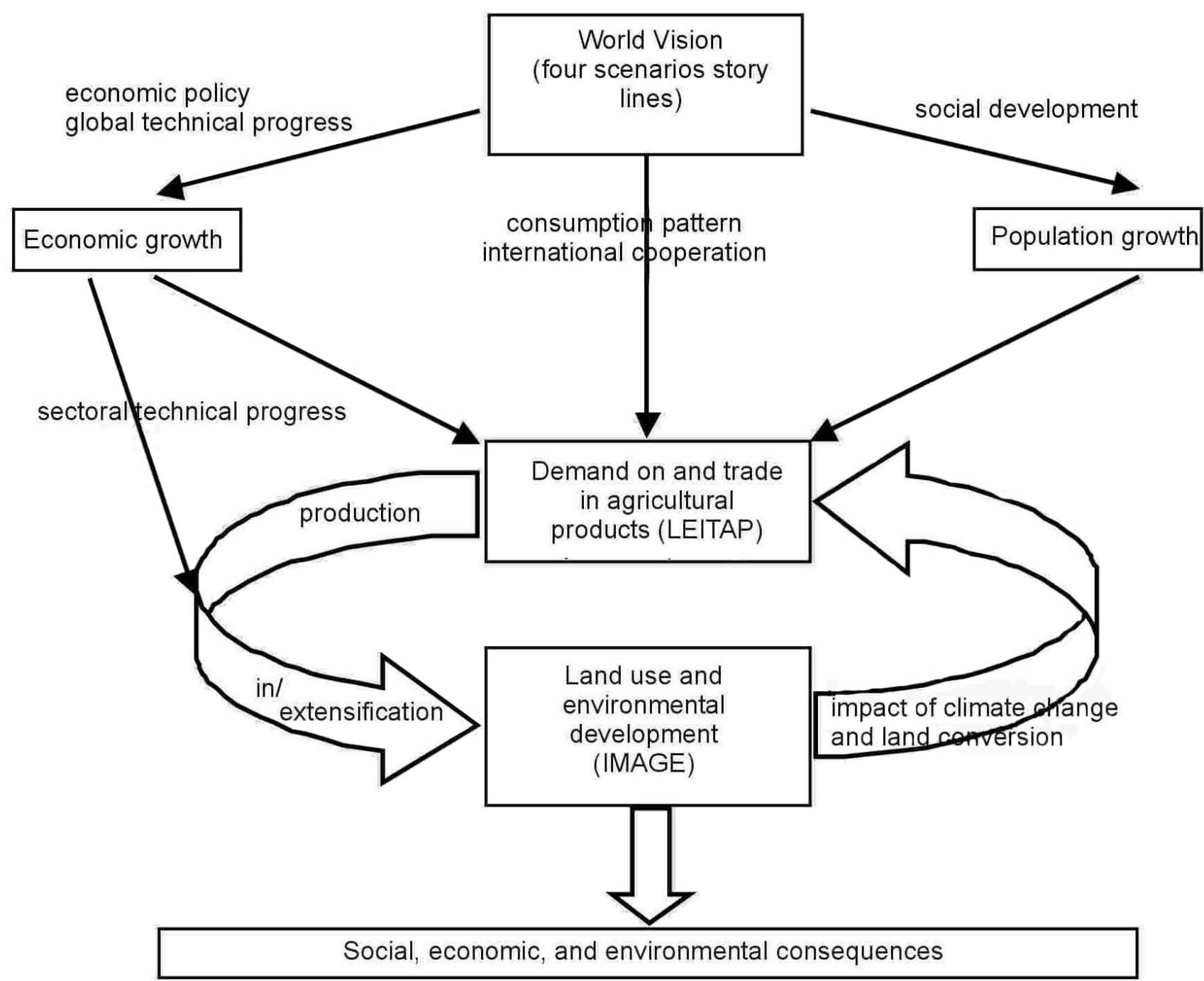

constant, e.g., import tariffs, export tariffs, and consumption subsidies were retained. Bilateral trade agreements, however, were not incorporated into the Baseline.

The first three scenarios analyzed the consequences of different agricultural policy options. Under the Baseline scenario, constant support to agriculture was assumed. Under CAP Liberalization, agricultural support was reduced stepwise for the EU, and under Global Liberalization, agricultural support was also cut outside the EU. All three scenarios assumed no mandatory blending of biofuels.

In the third policy scenario, the implementation of the EU Biofuels Directive was applied as an example of a mandatory blending obligation, and it illustrated the consequences of this biofuel policy on the national and international markets for agrifood products. In the Biofuel Ambition, a blending shares of $5.75 \%$ was applied in 2010 in each EU member state. 
Fig. 2. Land supply curve determining land conversion and land rental rate (source MNP 2006).

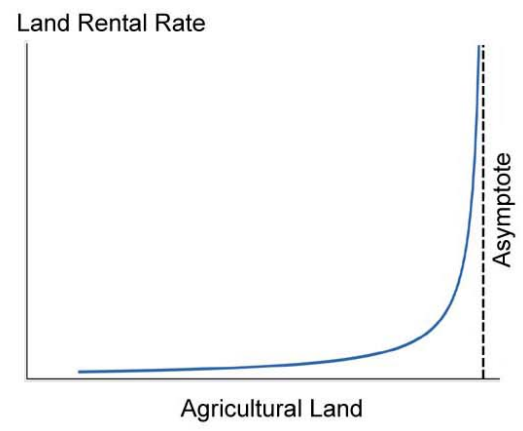

The crude oil price was assumed to be $26 \mathrm{USD} / \mathrm{bbl}$ in 2001. For the period 2001-2010, a trend that follows the development between 2001 and 2004 with an annual increase of around $12 \%$ was assumed. From 2010 to 2030 , the growth rates are smaller. The time frame of the simulations was 2000 to 2030 , and the results are shown at a global regional level (Table 2).

\section{Indicators}

The indicators used to show the impacts of the policy options were derived from IMAGE and LEITAP. Agricultural income and agricultural employment are results of LEITAP. Agricultural employment depends on changes in agricultural production, labor productivity, substitution of labor by other endowments, and demand for labor in other sectors. Agricultural income was calculated as revenue of agricultural sectors less intermediate production (i.e., value added) plus agricultural subsidies net of taxes. The intensity of agriculture, i.e., the management factor, was derived from the combination LEITAP-IMAGE (section Modeling Framework). It is an indicator for the use of inputs that increase production per hectare, e.g., fertilizers, pesticides, or mechanization. The indicators agricultural land, natural forests, and natural grasslands are all outputs of IMAGE. These indicators are driven by changes in agricultural production, agricultural intensity, and climate change. Finally, the $\mathrm{CO}_{2}$ balance was calculated within IMAGE for each grid cell. Each grid cell was divided into seven major $\mathrm{C}$ pools, in plants and in the soil (Klein Goldewijk et al. 1994). Climatic parameters, land cover, and atmospheric $\mathrm{C}$ concentrations determine the result of the $\mathrm{C}$ fluxes. In the scenarios analyzed here, land cover changes especially played an important role.

\section{BASELINE RESULTS}

The Baseline is a continuation of the year 2000 and shows an increase in total crop and animal production by $69 \%$ and $76 \%$, respectively, towards 2030 (Table 3). This is a result of increasing world population, which just passes 8 billion people in 2030, and increasing wealth. Increasing wealth for people with low incomes results in a shift in their diet towards more meat. Globally, GDP per capita (in Purchasing Power Parity) increases by $54 \%$ towards 2030. Major expansion of agricultural production takes place in Sub-Saharan Africa, Latin America (Brazil and the Rest of Latin America), and Asia. Several reasons underlie this development. One reason is that changes in diets and population are most pronounced in these regions. Another reason is that the Baseline does not take into account bilateral trade agreements. Because these include import tariffs for Brazilian beef, beef import will increase more than could be expected using current tariffs. Beef production in Brazil doubles in the Baseline, and the production of sugar in SubSaharan Africa increases by more than $300 \%$, for which high import tariffs at the border of the European Union exist. The decrease in sugar production in the EU15 (i.e., the 15 countries that entered the European Union before 2004) is also a consequence. Oil crops are increasingly produced 
Fig. 3. Input structure of biofuel production in LEITAP.

Capital-energy composite in GTAP-E

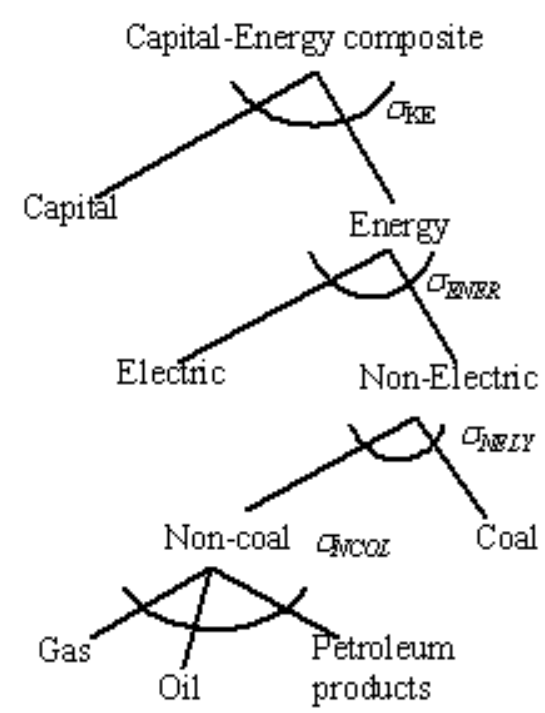

Input structure in the petrol eum sector

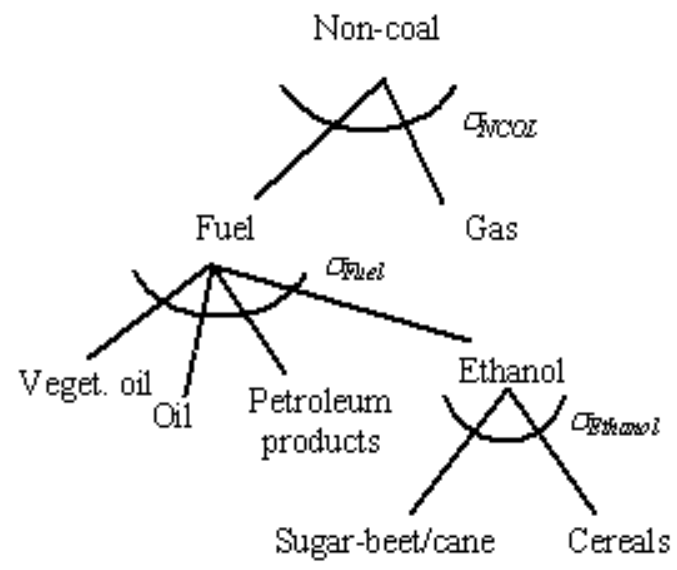

in Brazil and the USA, and are exported to Asia, mainly to China. Total agricultural area increases by $19 \%$ in 2030 compared to 2000. Sub-Saharan Africa accounts for $60 \%$ of this expansion. World market prices are decreasing for all specified commodities. Increase in agricultural production and land expansion is comparable to the results of the FAO outlook towards 2015/2030 (Bruinsma 2003).

\section{IMPACTS OF AGRICULTURAL TRADE LIBERALIZATION}

In this section, we compare the CAP Liberalization option and the Global Liberalization option with the Baseline to indicate the impacts of agricultural policy. Abolishment of subsidies on land, labor, or inputs, for example, and removal of trade barriers result in changes in real world prices and a shift in production locations across world regions. Table 4 shows the impacts for beef, temperate cereals, sugar, maize, and oil crops. Production locations of these agricultural products are particularly impacted by the two policy options. Growth in real world prices of these products towards 2030 is shown in Fig. 4.

In the CAP Liberalization option, only farmers within the European Union have to produce without any subsidy, whereas in the Global Liberalization options, everyone in the agricultural sector has to deal with the abolishment of subsidies. Therefore, production of temperate cereals, maize, and sugar in the EU is less affected in the Global Liberalization option than in the CAP Liberalization option (Table 4). The abolishment of direct income support plays an important role in the decrease of the European temperate cereal, maize, and oil crop production and the increase in other regions. The abolishment of subsidies on land in the USA is the most important reason for the decreasing production of these commodities in High Income Countries in the Global Liberalization option. The world market prices of temperate cereals, maize, and oil crops increase in the Global Liberalization option compared to the Baseline by $11 \%, 10 \%$, and $7 \%$, respectively. 
Table 1. Scenario assumptions under different scenarios.

\section{Baseline}

Trade policies

Domestic support in agriculture

Production quotas

Biofuels

Set aside

\section{CAP $^{\dagger}$ Liberalization (CL)}

Trade policies

Domestic support in agriculture

Production quotas

Biofuels

Set aside

\section{Global Liberalization (GL)}

Trade policies

Domestic support in agriculture

Production quotas

Biofuels

Set aside

\section{Biofuel Ambition (GL+BA)}

Trade policies

Domestic support in agriculture

Production quotas

Biofuels

Set aside
Constant policies

Constant policies

Constant policies

No blending obligations

Constant policies
Stepwise reduction of price support in the European Union (EU)

- 2010: $25 \%$ reduction compared with 2001

- 2020: 50\% reduction compared with 2010

-2030: abolished

CAP reform 2003: full decoupling

- For the European Union only

- 2010: 25\% reduction of domestic support, new EU member states'

domestic agricultural support agreed by EU minus $25 \%$ reduction

- 2020: $50 \%$ reduction compared to 2010

-2030: abolished

2020: abolished in the EU

No blending obligations

Abolished in EU15 in 2010, never introduced in New Member States

Stepwise reduction of price support and import tariffs at global level

-2010: $25 \%$ reduction compared with 2001

- 2020: $50 \%$ reduction compared with 2010

- 2030: abolished

For the EU as under "CAP Liberalization"

For non-EU countries

-2010: $25 \%$ reduction compared with 2001

- 2020: 50\% reduction compared with 2010

-2030: abolished

As under "CAP Liberalization"

As under "CAP Liberalization"

As under "CAP Liberalization"

As under "Global Liberalization"

As under "Global Liberalization"

As under "Global Liberalization"

Biofuel share in transportation fuel $5.75 \%$ in 2010

As under "Global Liberalization"

\section{$\nmid$ CAP: Common Agricultural Policies}


Table 2. Definitions of aggregated regions.

\begin{tabular}{ll}
\hline \hline EU15 $\dagger$ & $\begin{array}{l}\text { Austria, Belgium, Denmark, Finland, France, Germany, Greece, Ireland, Italy, } \\
\text { Luxembourg, Netherlands, Portugal, Spain, Sweden, UK (all member states that } \\
\text { entered the European Union before 2004) }\end{array}$ \\
EU12 & $\begin{array}{l}\text { Bulgaria, Cyprus, Czech republic, Estonia, Hungary, Latvia, Lithuania, Malta, } \\
\text { Poland, Romania, Slovenia, Slovakia (all member states that entered the European } \\
\text { Union after 2004) }\end{array}$ \\
High Income Countries & $\begin{array}{l}\text { Organisation for Economic Co-operation and Development (OECD) countries except } \\
\text { EU27 }\end{array}$ \\
Sub-Saharan Africa & African countries beyond the Sahara, excl. Republic of South Africa \\
Brazil & Brazil \\
Rest of Latin America & Central and South America, except for Brazil \\
Asia & South and South Eastern Asia, except for China \\
China & China \\
Former Soviet Union & Former Soviet Union
\end{tabular}

$\dagger$ EU: European Union

The sugar market in the EU is highly protected by import quota. In the CAP Liberalization scenario, the abolishment of this quota causes a substantial increase in import of sugar to the EU. The real world market price of sugar decreases (Fig. 4). Especially, the Rest of Latin America, Sub-Saharan Africa, and Brazil export sugar for European consumption, almost twice the amount of the Baseline. In the Global Liberalization option, the abolishment of import tariffs on sugar in High Income Countries (USA) causes a decrease in the production of sugar in this region, which is set off by an increase in the production and export of sugar in the Rest of Latin America and Brazil.

In the CAP Liberalization option, beef production in the EU15 is especially affected by the full decoupling, which leads to more European import of beef from Brazil. Thirty percent of the increased beef production in Brazil in the CAP Liberalization option is exported to Europe. Real market price of beef within Brazil increases strongly in the CAP Liberalization option compared to the Baseline. The world market price of beef increases up to $6 \%$ in the Global Liberalization option.
The shifts in agricultural production towards other regions will impact land use and related socioeconomic and environmental indicators. The agricultural sector and the rural population profit from higher income and employment. On the other hand, changes in land use and land management affect the environment and biodiversity. Intensification of agriculture can harm the environment due to the leaching of nutrients and use of chemicals but at the same time results in a decline in the area needed for agriculture. The spider diagrams in Fig. 5 show the trade-off between those socioeconomic and environmental indicators. Since the impacts of the two policy options are concentrated in EU15, EU12, High Income Countries, and Brazil, these regions are shown.

In the EU15, a positive trade-off towards natural grasslands and forests occurs in both policy scenarios. The decrease in agricultural production compared to the Baseline drives abandonment of agricultural land; therefore, more area is left for natural areas. The grasslands are especially allocated in the Mediterranean area, where the additional abandonment, compared to the Baseline, 
Table 3. Changes in production and market prices in the Baseline of beef, temperate cereals, sugar, maize, and oil crops and for the aggregates "total crop products" and "total animal products" (2030 relative to 2000).

\begin{tabular}{lrrrrrrr}
\hline \hline & Beef & $\begin{array}{r}\text { Temperate } \\
\text { cereals }\end{array}$ & Sugar & Maize & Oil crops & $\begin{array}{r}\text { Total crop } \\
\text { products }\end{array}$ & $\begin{array}{r}\text { Total animal } \\
\text { products }\end{array}$ \\
\hline Production (volume) $\dagger$ & & & & & & & \\
EU15 & $4 \%$ & $42 \%$ & $-18 \%$ & $32 \%$ & $36 \%$ & $37 \%$ & $5 \%$ \\
EU12 & $57 \%$ & $21 \%$ & $29 \%$ & $30 \%$ & $35 \%$ & $27 \%$ & $15 \%$ \\
HIC & $36 \%$ & $77 \%$ & $9 \%$ & $68 \%$ & $119 \%$ & $75 \%$ & $40 \%$ \\
SSA & $286 \%$ & $179 \%$ & $334 \%$ & $183 \%$ & $176 \%$ & $173 \%$ & $309 \%$ \\
Brazil & $104 \%$ & $175 \%$ & $94 \%$ & $173 \%$ & $151 \%$ & $135 \%$ & $114 \%$ \\
RLA & $91 \%$ & $73 \%$ & $89 \%$ & $71 \%$ & $68 \%$ & $65 \%$ & $94 \%$ \\
Asia & $122 \%$ & $70 \%$ & $178 \%$ & $83 \%$ & $127 \%$ & $66 \%$ & $177 \%$ \\
China & $90 \%$ & $64 \%$ & $79 \%$ & $77 \%$ & $54 \%$ & $47 \%$ & $78 \%$ \\
FSU & $47 \%$ & $28 \%$ & $50 \%$ & $39 \%$ & $47 \%$ & $30 \%$ & $50 \%$ \\
World & $75 \%$ & $56 \%$ & $60 \%$ & $79 \%$ & $103 \%$ & $69 \%$ & $76 \%$ \\
Market prices & & & & & & & \\
World & $-26 \%$ & $-24 \%$ & $-14 \%$ & $-25 \%$ & $-17 \%$ & & \\
\hline
\end{tabular}

$\dagger$ EU: European Union; HIC: High Income Countries; SSA: Sub-Saharan Africa; RLA: Rest Latin America; FSU: Former Soviet Union

mostly takes place. The change in suitability for agriculture due to climate change in these areas drives this process. Besides abandonment, the use of inputs in agriculture is less. On the other hand, the income of the agricultural sector decreases by $40 \%$ compared to the Baseline results. Agricultural employment slightly decreases compared to the Baseline.

In the new EU-member states (EU12), the situation is different since these countries entered the EU within the scenario period. Therefore, the introduction of the subsidies in the Common Agricultural Policies results in more than a tripling of the agricultural income in this region in the Baseline. Abolishment of these subsidies in the CAP Liberalization scenario and the Global Liberalization scenario accordingly results in a $55 \%$ decrease in agricultural income in both scenarios. The impacts of the liberalization scenarios on natural areas and agricultural employment are nihil. Finally, the management of agriculture is less intense in the liberalization scenarios compared to the Baseline.

Due to the current domestic agricultural policies, the impact of CAP abolishment in High Income Countries is very low. The impact of the Global Liberalization scenario is positive for the environment because it results in a small increase in natural forest and grassland areas. On the other hand, it is negative because intensity of agriculture management is increasing. Both processes are especially driven by the abolishment of land-related subsidies. This abolishment also causes the decrease in income of the agricultural sector compared to the Baseline. Finally, the decrease in production 
Table 4. Changes in the production of beef, temperate cereals, sugar, maize, and oil crops in the CAP $\dagger$ Liberalization scenario (CL), the Global Liberalization scenario (GL), and the Biofuel Ambition scenario $(\mathrm{GL}+\mathrm{BA})$ relative to the Baseline.

\begin{tabular}{|c|c|c|c|c|c|c|c|c|c|c|c|c|c|c|c|}
\hline & \multicolumn{3}{|c|}{ Beef } & \multicolumn{3}{|c|}{ Temperate cereals } & \multicolumn{3}{|c|}{ Sugar } & \multicolumn{3}{|c|}{ Maize } & \multicolumn{3}{|c|}{ Oil crops } \\
\hline & CL & GL & $\begin{array}{r}\text { GL+ } \\
\text { BA }\end{array}$ & CL & GL & $\begin{array}{r}\text { GL+ } \\
\text { BA }\end{array}$ & CL & GL & $\begin{array}{r}\text { GL+ } \\
\text { BA }\end{array}$ & CL & GL & $\begin{array}{r}\text { GL+ } \\
\text { BA }\end{array}$ & CL & GL & $\begin{array}{r}\text { GL+ } \\
\text { BA }\end{array}$ \\
\hline EU15 & $-22 \%$ & $-26 \%$ & $-26 \%$ & $-14 \%$ & $-10 \%$ & $-12 \%$ & $-158 \%$ & $-60 \%$ & $-55 \%$ & $-17 \%$ & $-12 \%$ & $-6 \%$ & $-20 \%$ & $-21 \%$ & $-13 \%$ \\
\hline EU12 & $-11 \%$ & $-27 \%$ & $-27 \%$ & $-3 \%$ & $-4 \%$ & $-5 \%$ & $-48 \%$ & $-33 \%$ & $-31 \%$ & $-6 \%$ & $-7 \%$ & $-2 \%$ & $-3 \%$ & $0 \%$ & $7 \%$ \\
\hline $\mathrm{HIC}$ & $-1 \%$ & $-3 \%$ & $-3 \%$ & $2 \%$ & $-18 \%$ & $-18 \%$ & $2 \%$ & $-9 \%$ & $-8 \%$ & $2 \%$ & $-18 \%$ & $-17 \%$ & $1 \%$ & $-15 \%$ & $-14 \%$ \\
\hline SSA & $3 \%$ & $-1 \%$ & $-1 \%$ & $5 \%$ & $-2 \%$ & $-1 \%$ & $11 \%$ & $14 \%$ & $18 \%$ & $1 \%$ & $-2 \%$ & $-2 \%$ & $0 \%$ & $26 \%$ & $27 \%$ \\
\hline Brazil & $44 \%$ & $36 \%$ & $36 \%$ & $4 \%$ & $5 \%$ & $4 \%$ & $20 \%$ & $60 \%$ & $62 \%$ & $6 \%$ & $-4 \%$ & $8 \%$ & $-3 \%$ & $10 \%$ & $14 \%$ \\
\hline RLA & $1 \%$ & $-4 \%$ & $-4 \%$ & $4 \%$ & $9 \%$ & $9 \%$ & $21 \%$ & $53 \%$ & $57 \%$ & $4 \%$ & $2 \%$ & $5 \%$ & $2 \%$ & $12 \%$ & $13 \%$ \\
\hline Asia & $1 \%$ & $-9 \%$ & $-9 \%$ & $2 \%$ & $-5 \%$ & $-5 \%$ & $1 \%$ & $-2 \%$ & $-2 \%$ & $1 \%$ & $-5 \%$ & $-5 \%$ & $0 \%$ & $-7 \%$ & $-7 \%$ \\
\hline China & $0 \%$ & $0 \%$ & $0 \%$ & $0 \%$ & $-3 \%$ & $-3 \%$ & $4 \%$ & $-55 \%$ & $-54 \%$ & $0 \%$ & $-3 \%$ & $-3 \%$ & $0 \%$ & $-6 \%$ & $-5 \%$ \\
\hline FSU & $3 \%$ & $-6 \%$ & $-6 \%$ & $0 \%$ & $2 \%$ & $2 \%$ & $1 \%$ & $-14 \%$ & $-13 \%$ & $3 \%$ & $3 \%$ & $7 \%$ & $1 \%$ & $3 \%$ & $8 \%$ \\
\hline World & $4 \%$ & $-1 \%$ & $-1 \%$ & $-2 \%$ & $-7 \%$ & $-8 \%$ & $-1 \%$ & $-2 \%$ & $-1 \%$ & $1 \%$ & $-10 \%$ & $-8 \%$ & $-1 \%$ & $-4 \%$ & $-2 \%$ \\
\hline
\end{tabular}

$†$ CAP: Common Agricultural Policies

\$ EU: European Union; HIC: High Income Countries; SSA: Sub-Saharan Africa; RLA: Rest Latin

America; FSU: Former Soviet Union

compared to the Baseline also causes a decrease in agricultural employment.

Both policy scenarios have different impacts on the agricultural sector and land use in Brazil. The area of natural forest and grasslands will decrease even more in the CAP liberalization and Global Liberalization scenarios compared to the Baseline. Especially, savanna is converted towards agricultural area. Additionally, the increase in the intensity of agricultural management in both policy scenarios is higher than in the Baseline. In the CAP Liberalization scenario, this is partly caused by subsidies on inputs in Brazil, which are abolished in the Global Liberalization scenario. The growth of the agricultural production sector in both scenarios compared to the Baseline results in a greater increase in agricultural employment and greater agricultural income. The higher prices of agricultural products and higher production in the Global Liberalization scenario have a positive effect on agricultural income in Brazil.

Land use-related $\mathrm{CO}_{2}$ emissions increase in both liberalization options (Fig. 6) due to the expansion of agricultural area. Land conversions in the Baseline lead to $60 \mathrm{Pg} \mathrm{CO}_{2}$ emissions from 2000 to 2030. Land use emissions increase less in the Global Liberalization option since less land is used in High Income Countries due to the abolishment of landrelated subsidies (especially in the USA). Land conversions in Brazil count for the largest part of the extra emissions. 
Fig. 4. Change in real world prices of beef, temperate cereals, sugar, maize, and oil crops in the Common Agricultural Policies (CAP) Liberalization option, the Global Liberalization option, and the Biofuel Ambition option relative to the Baseline in 2030.

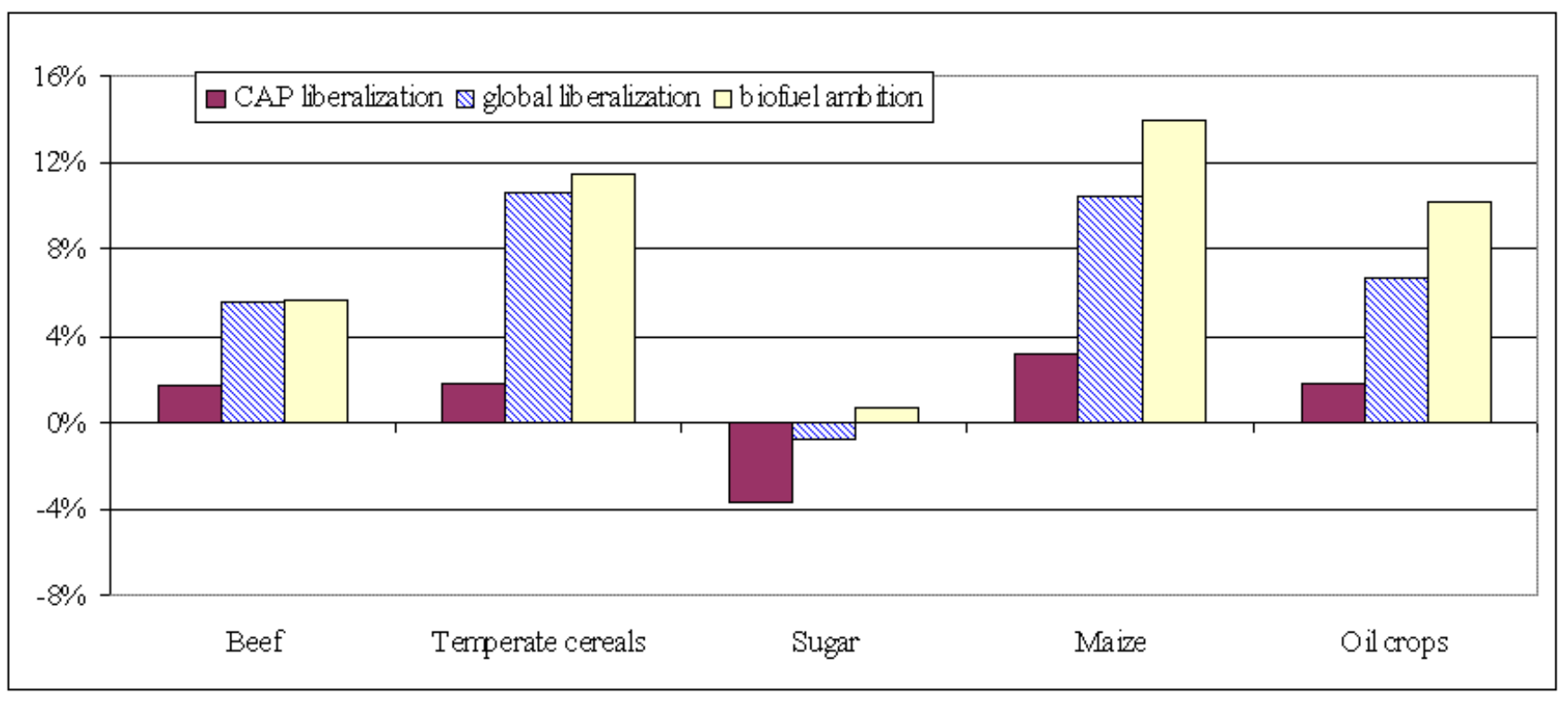

\section{IMPACT OF EUROPEAN BIOFUEL POLICIES}

In this section, we compare the Biofuel Ambition option to the Global Liberalization option. The implementation of a mandatory blending target causes an increase in demand for biofuel crops in the biofuel option. Consequently, market prices decrease less than in the Global Liberalization option. The higher price within the EU drives an increase in production, not only in Europe but also in other regions of the world (Table 4). The obligated blending targets result in a relative increase in real world prices, especially for maize and oilseeds (Fig. 4).

Mainly maize, oilseeds, and sugar have been used as inputs for biodiesel or ethanol; therefore, we focus on these agricultural commodities. Maize production is increasing substantially in Brazil. Although this region is not the largest producer of maize, in the Biofuel Ambition scenario, it is, together with Former Soviet Union, High Income Countries, and the Rest of Latin America, one of the major exporters of maize to Europe. In the Biofuel
Ambition option, oilseeds are especially imported from Brazil and High Income Countries. Sugar production takes place mainly in Sub-Saharan Africa, Brazil, and Rest of Latin America for export to the EU. The imports of all biofuel crops together into the EU are $60 \%$ higher in the Biofuel Ambition option compared to the Global Liberalization option. The amount of oilseeds imported is even higher than the amount produced within the EU, and the volume of imported maize is $35 \%$ of the volume produced within the EU.

The spider diagrams in Fig. 7 show the trade-off between the environment and agricultural income and employment in three regions under the Biofuel Ambition option and the Global Liberalization option. In these regions, production changes the most between the biofuel option and the Global Liberalization scenario.

Within the EU15, the agricultural sector increases slightly compared to the Global Liberalization scenario. The Biofuel Ambition option results in a small increase in agricultural income and an expansion of agricultural area. This expansion is 
Fig. 5. Trade-offs between environmental indicators, i.e., natural forest, natural grassland, and intensity of agricultural management, and socioeconomic indicators, i.e., agricultural income and agricultural employment in EU15, EU12, High Income Countries (HIC), and Brazil in the Common Agricultural Policies (CAP) Liberalization option and the Global Liberalization option compared to the Baseline.
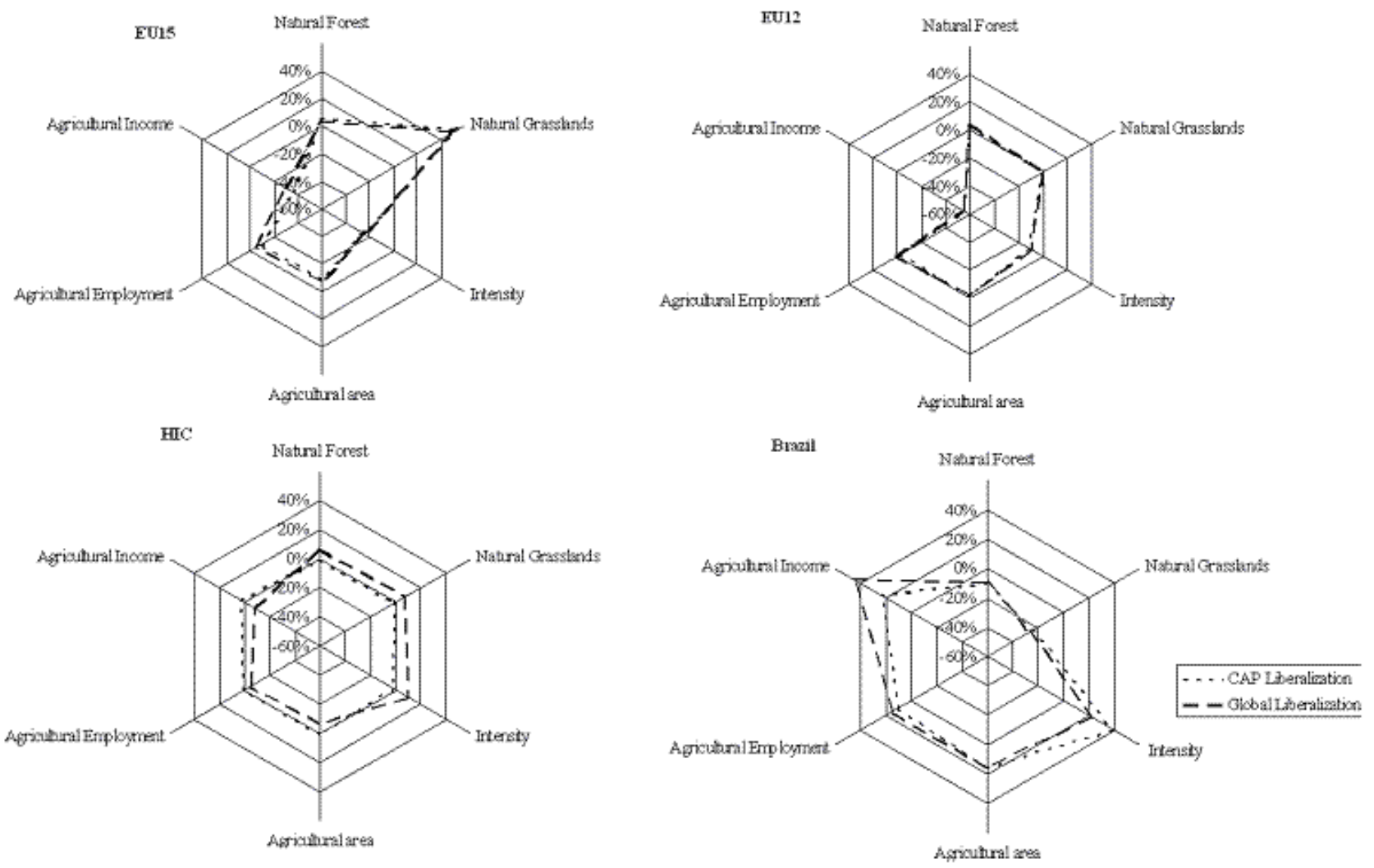

especially at the cost of natural grasslands. The area of natural grasslands increases in the Global Liberalization option due to the abandonment of agricultural areas. In the EU12, especially the intensity of agriculture increases as an effect of the Biofuel Ambition option. In other words, the factor "land" has been substituted by capital and labor; therefore, yields are higher than in the Baseline. Changes in natural area, agricultural income, or employment are very small. Impacts of the Biofuel Ambition scenario are greatest in Brazil. Agricultural income and agricultural employment increase both in the Biofuel Ambition scenario. Agricultural area expands compared to the Global Liberalization scenario, and the agricultural area will be more intensively managed. Additionally, the area of natural forest decreases.
Global land use-related $\mathrm{CO}_{2}$ emissions increase by $5 \%$ from 2000 to 2010 compared to the Baseline but decrease by $2 \%$ in the Global Liberalization option (Fig. 6). The $5.75 \%$ blending target has to be fulfilled from 2010 onwards. Therefore, most of the land conversion to expand agricultural land to produce biofuels takes place during this period. After 2010, land-related $\mathrm{CO}_{2}$ emissions are slightly greater in the Biofuel Ambition option compared to the Global Liberalization scenario.

\section{SENSITIVITY OF RESULTS}

The results of this analysis have to be interpreted in the context chosen for the Baseline scenario. Population growth and macro-economics are key 
Fig. 6. Difference in cumulative land use-related $\mathrm{CO}_{2}$ emissions in the Common Agricultural Policies (CAP) Liberalization, the Global Liberalization option, and the Biofuel Ambition option compared to the Baseline.

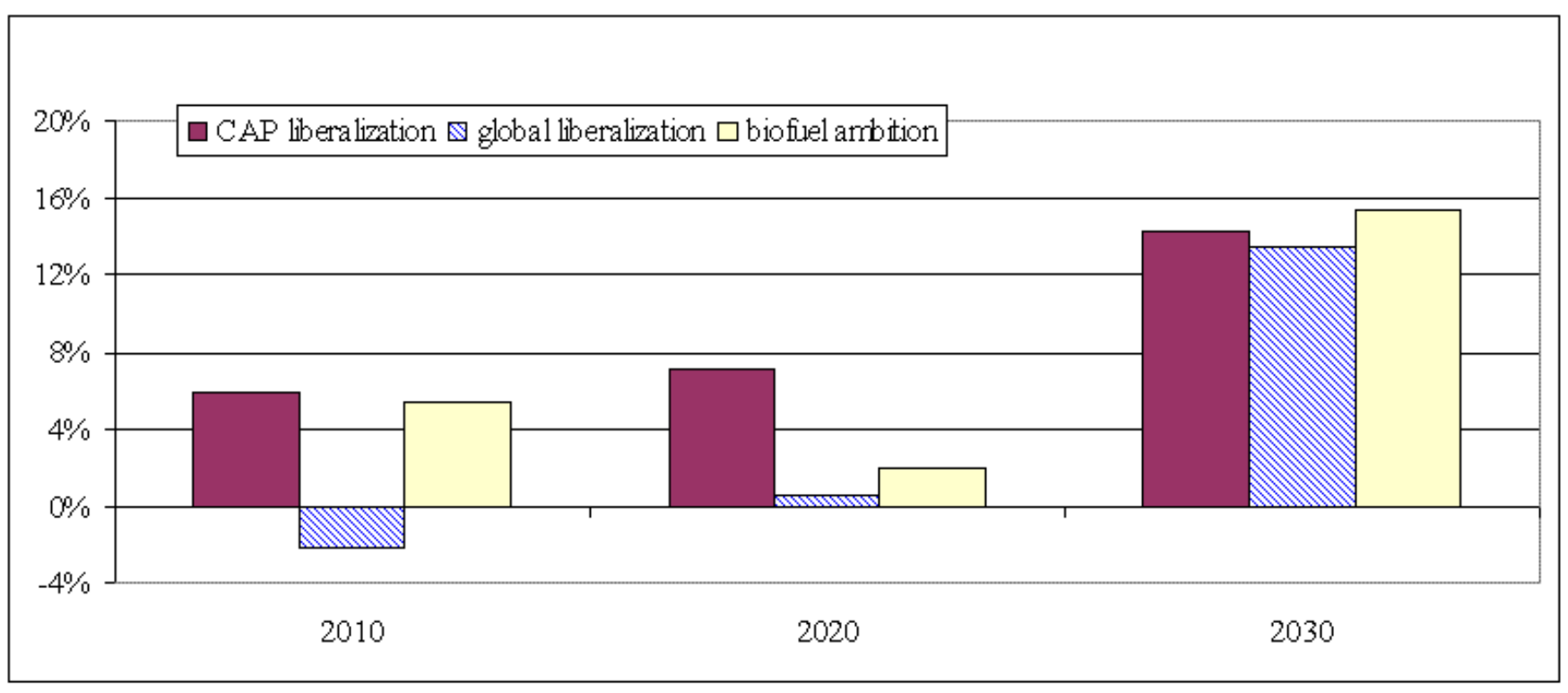

drivers of agricultural demand and production. Both are taken as an assumption, whereas their uncertainty is high. Van Meijl et al. (2006) conducted a sensitivity analysis to test the robustness of the results of the LEITAP/IMAGE combination with respect to demographic and economic developments. Confidence intervals depend on regional land characteristics and the extent of macro-economic or population growth: the larger the possibilities to expand agricultural land or the higher the economic growth, the wider the confidence interval is. Shocks in population growth result in lower standard deviations than those associated with shocks in economic growth.

In this paper, we show the impacts of the implementation of the biofuel directive in a Global liberalization scenario. Impacts of the biofuel directive in four contrasting scenarios can be found in Rienks (2008). In a context without trade liberalization, most biofuel crops will be produced in the European Union. However, more than one third will be imported from other regions. More elaborative information about assumptions in the context and their elaboration towards the indicators can be found in Eickhout and Prins (2008).

Next to the assumption of the Baseline, several model parameters play a crucial role. One of the crucial factors in the model is the assumption about elasticities depicting the shift in endowments for agricultural production (land, labor, capital). Elasticities that define the ability of substituting land used for one crop (e.g., vegetables and fruit) for another crop (like wheat) are other important factors. A sensitivity analysis of these assumptions will be examined in the near future.

\section{DISCUSSION}

In this paper, we presented impacts of changes in European and global trade policies and European biofuel policies on environmental and socioeconomic indicators in other regions of the world. Our analysis shows that all policy options affect prices, trade patterns, and production of agricultural commodities in different regions. Therefore, land use, land use 
Fig. 7. Trade-offs between environmental indicators, i.e., natural forest, natural grassland, and intensity of agricultural management, and socioeconomic indicators, i.e., agricultural income and agricultural employment in EU15, EU12, and Brazil in the Biofuel Ambition option compared to the Baseline.
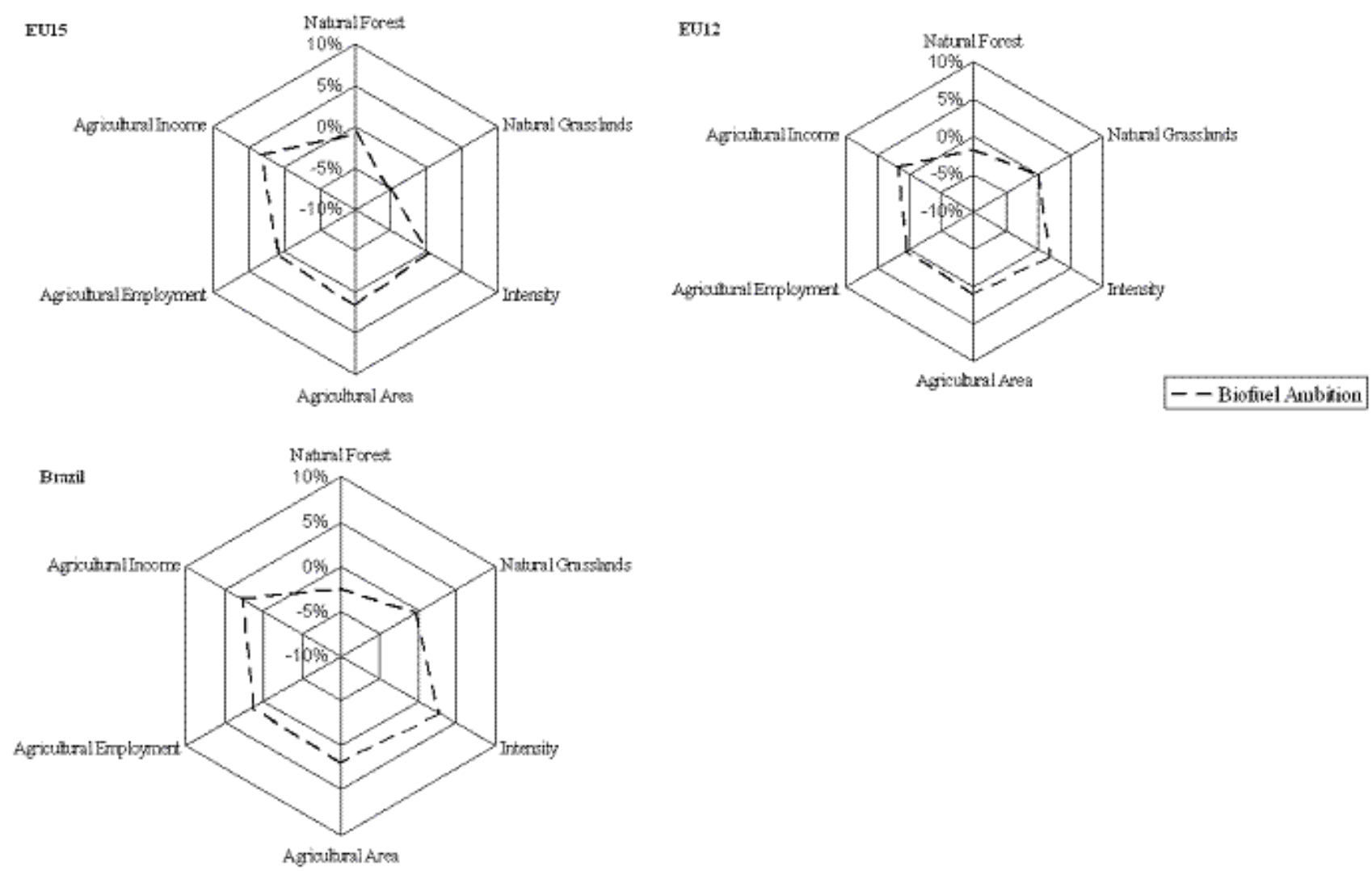

management, and agricultural income and employment in other regions are also affected by changes in these policies.

Brazil appears to be the most sensitive region to changes in European agricultural and biofuel policies and global trade liberalization. Agricultural production in Brazil increases in the CAP Liberalization option, the Global Liberalization option, and the Biofuel Ambition option. Current trade structures play an important role here. Currently, Brazil is one of the largest exporters of beef; it is responsible for one third of global beef exports, whereas beef production in the Rest of Latin America is only $\pm 25 \%$ of the production in Brazil (FAPRI 2004). Another factor is the ability to increase agricultural production by expansion or intensification. In 1998, 65\% of Brazil's total area was still potentially available for agricultural production (Schnepf et al.2001). Although land use change is driven by a complex system of several driving forces, globalization and access to global markets have major impacts (Lambin et al. 2001). Both agricultural expansion and agricultural intensification are important drivers of biodiversity loss (Matson et al. 1997, Millennium Ecosystem Assessment 2005). These two drivers increase in Brazil in the analyzed policy options, which implies that changes in biofuel and trade policies in regions other than Brazil can indirectly harm ecosystems and biodiversity in Brazil.

Besides the vulnerability of ecosystems in tropic regions (e.g., Brazil) with respect to biodiversity 
(Myers et al. 2000, Mittermeier et al. 2003), a lot of carbon has been stored in those ecosystems (PBL 2010). Changing agricultural trade policies changes global production patterns; therefore, natural habitats are converted into agriculture. On the other hand, agricultural areas in the EU and North America have been abandoned, and regrowth of natural vegetation is occurring on this areas. However, the uptake of carbon during the regrowth of natural habitats on abandoned areas does not compensate for the $\mathrm{CO}_{2}$ emitted due to clearing of natural habitats.

In the biofuel option, land-related emissions are especially high in the first decade. This is a result of the biofuel blending target, which has to be met in 2010. Land will be cleared in the first decade to produce the extra food or feed crops. The so-called "carbon debt" that results from clearing natural habitats should be repaid before biofuels are $\mathrm{CO}_{2}$ neutral. For example, the conversion of tropical forest has a carbon payback time of more than 50 years to centuries, depending on the crops cultivated for biofuels or biodiesel (Fargione et al. 2008, Gibbs et al. 2008).

The socioeconomic indicators are positive for those regions that expand their production due to liberalization or biofuel policies. World market prices increase in all policy options except for sugar in the CAP Liberalization option. The same regions profit from the increasing world market price because they can increase their agricultural export. This results in an increase in agricultural income. On the other hand, Fabiosa et al. (2005) concluded that net importing countries will feel the negative impacts of increasing agricultural prices. This was the reality in several food importing countries during the high food prices in 2008 (FAO 2008).

According to Taheripour et al. (2008), including byproducts used as feed component for animals in the model framework will decrease areas needed for biofuel crops under biofuel mandates. However, the impact differs by region. The USA and EU increase their oilseeds area (by $2.5 \%$ and $1.9 \%$, respectively) when by-products are included (Taheripour et al. 2008). Oilseed areas in temperate zones will increase because crops that were not profitable to grow for biofuels will be more profitable with byproducts included. Therefore, larger areas in the EU will be dedicated to biofuel crops than in Brazil, for example. In that case, the emission balance will also be different: less expansion in Brazil and more use of "old" agricultural areas in the EU and USA will result in decreased $\mathrm{CO}_{2}$ emissions. Another frequently mentioned point is the use of second generation biofuel crops. However, these crops are not expected to offer a viable large scale alternative before 2020 (Fairless 2007, Himmel 2007). In our analysis, the biofuel option includes only the European biofuel directive, but more regions do introduce biofuel policies at the moment, which increases the demand for biofuels. Therefore, the market for biofuel crops will become even tighter, and the global food crop area will increase by more than $10 \%$ (Stehfest et al. 2009).

Since changes in agricultural-related policies impact agricultural production in other regions, many trade-offs have to be taken into account. An example of taking into account the impacts of biofuel policies in other regions are the sustainability criteria included within the European biofuel directive (EC 2008). The debate is still going on regarding the kind of criteria that will be applied to achieve a desirable effect. So far, the criteria apply especially at the consignment level and do not take into account the displacement of other crops due to the additional pressure on agricultural production elsewhere. These indirect effects may also impact biodiversity and carbon emissions by land conversion practices (Eickhout et al. 2008a).

To avoid trade-offs when changing policies, policy responses need to be designed across scales and sectors. Merely looking at the agriculture or energy sector often does not take into account impacts on climate change or poverty. Besides, considering the abolishment of CAP subsidies only at the European scale can show a positive effect for European biodiversity due to abandonment or less intensive management. However, the impact on biodiversity globally can be negative due to changing agricultural trade patterns, expansion of agricultural land towards natural areas, and intensification of management systems.

\section{CONCLUSIONS}

In this paper, we show the regional impact of changes in European agricultural and biofuel policies. Because of the assumed population and welfare increase in the Baseline scenario, global agricultural production and agricultural land use increases considerably towards 2030 . Changes in policies especially affect agricultural production 
and land use in specific regions. Shifting trade patterns, changes in agricultural production, and expansion of agricultural area or intensification of agriculture result in changes in land use and land use emissions. Higher prices for agricultural crops on the world market, together with changing production, raise agricultural income. Brazil is the region most affected due to its current trade and production patterns and the immense amount of potentially productive area. Although agricultural income in Brazil increases in all options, the area of natural forests and grasslands, and hence biodiversity, decreases. Global land-related $\mathrm{CO}_{2}$ emissions rise due to shifting land patterns: land clearing in Brazil accounts for a rise in $\mathrm{CO}_{2}$ emissions, whereas regrowth of natural areas on abandoned land in Europe and the USA reduces land-related $\mathrm{CO}_{2}$ emissions in those regions. Because expected population growth and wealth increase in the Baseline scenario result in increasing agricultural production and expansion of agricultural area, the need for sustainable use of ecosystem goods and services, like water provision, climate regulation, or carbon storage will also increase without any changes in policies. Although policies have relatively little impact in that sense, arrangements or policies that avoid negative impacts of changing agricultural or biofuel policies in the European Union on other regions will be needed because those impacts could undo positive impacts within the European Union or in other regions.

Responses to this article can be read online at: http://www.ecologyandsociety.org/voll6/iss 1/art49/ responses/

\section{Acknowledgments:}

The work in this paper has been conducted as part of the Eururalis project commissioned by the Dutch Ministry of Agriculture, Nature and Food Quality. We would like to thank the two anonymous reviewers for their constructive comments. Further, we would like to thank Henk Westhoek, Elke Stehfest, and Ton Manders (PBL) for their extensive and useful comments.

\section{LITERATURE CITED}

Alcamo, J., editor. 1994. IMAGE 2.0: integrated modelling of global climate change. Water, Air and Soil Pollution 76(1-2).

Alcamo, J., R. Leemans, and E. Kreileman, editors. 1999. Global change scenarios of the $21^{\text {st }}$ century. Results from the IMAGE 2.1 model. Pergamon \& Elseviers Science, London, UK.

Banse, M., H. van Meijl, A. Tabeau, and G. Woltjer. 2008. Will EU biofuel policies affect global agricultural markets? European Review of Agricultural Economics 35:117-141.

Birur, D. K., T. W. Hertel, and W. E. Tyner. 2008. Impact of biofuel production on world agricultural markets: a computable general equilibrium analysis. GTAP Working Paper No. 53. Center for Global Trade Analysis. Purdue University, West Lafayette, Indiana, USA.

Bruinsma, J. 2003. World agriculture towards 2015/2030: an FAO perspective. Food and Agriculture Organization of the United Nations, Rome, Italy.

Burniaux, J. M., and T. P. Truong. 2002. GTAP-E: an energy-environmental version of the GTAP model. GTAP Technical Paper No. 16. Center for Global Trade Analysis. Purdue University, West Lafayette, Indiana, USA.

Douglas, E. M., K. Sebastian, C. J. Vörösmarty, S. Wood, and K. M. Chomitz. 2005. The role of tropical forests in supporting biodiversity and hydrological integrity. World Bank Policy Research Paper 3635.

Eickhout, B., and A. G. Prins. 2008. Eururalis 2.0. Technical background and indicator documentation. Wageningen, The Netherlands. [online] URL: http: //www.eururalis.eu/current/background/documents/ TechnicalDocument2.pdf.

Eickhout, B., G. J. van den Born, J. Notenboom, M. van Oorschot, J. P. M. Ros, D. P. van Vuuren, and H. J. Westhoek. 2008a. Local and global consequences of the EU renewable directive for biofuels. Testing the sustainability criteria. MNP Report 500143001, Netherlands Environmental Assessment Agency (MNP), Bilthoven, the 
Netherlands. [online] URL: http://www.rivm.nl/bib liotheek/rapporten/500143001.pdf.

Eickhout, B., H. van Meijl, and A. Tabeau. 2006. Modelling agricultural trade and food production under different trade policies. In Netherlands Environmental Assessment Agency (MNP). 2006. Integrated modelling of global environmental change. An overview of IMAGE 2.4. Bilthoven, The Netherlands.

Eickhout, B., H. van Meijl, A. Tabeau, and T. van Rheenen. 2007. Economic and ecological consequences of four European land-use scenarios. Land Use Policy 24:562-575.

Eickhout, B., H. van Meijl, A. Tabeau, and E. Stehfest. 2008b. The impact of environmental and climate constraints on global food supply. In T. Hertel, S. Rose, and R. Tol, editors. Economic analysis of land use in global climate change policy. Routledge, USA, in press.

European Commission (EC). 2008. Proposal for a directive of the European parliament and of the Council on the promotion of the use of energy from renewable sources. European Commission, COM (2008) 30 final. Brussels, Belgium.

Fabiosa, J., J. Beghin, S. de Cara, A. Elobeid, C. Fang, M. Isik, H. Matthey, A. Saak, P. Westhoff, D. Scott Brown, B. Willot, D. Madison, S. Meyer, and J. Kruse. 2005. The Doha round of the World Trade Organization and agricultural markets liberalization: impacts on developing economies. Review of Agricultural Economics 27:317-335.

Fairless, D. 2007. Biofuel: the little shrub that could - maybe. Nature 449:652-655.

Fargione, J., J. Hill, D. Tilman, S. Polasky, and P. Hawthorne. 2008. Land clearing and the biofuel debt. Science 319:1235-1238.

Food and Agriculture Organization of the United Nations (FAO). 2008. Soaring food prices: facts, perspectives, impacts and actions required. FAO Document HLC/08/INF/1, accompanying the HighLevel Conference on World Food Security: The challenges of climate change and bioenergy. Food and Agriculture Organization of the United Nations, Rome, Italy. [online] URL: http://www.fao.org/file admin/user upload/foodclimate/HLCdocs/HLC08inf-1-E.pdf.
Food and Agricultural Policy Research Institute (FAPRI). 2004. U.S. and world agricultural outlook. Food and Agricultural Policy Research Institute, Iowa State University, Ames, Iowa, USA.

Francois, J., H. Van Meijl, and F. Van Tongeren. 2005. Trade liberalization and developing countries under the Doha round. Economic Policy 2042:349-391.

Gibbs, H. K., M. Johnston, J. A. Foley, T. Holloway, C. Monfreda, N. Ramankutty, and D. Zaks. 2008. Carbon payback times for crop-based biofuel expansion in the tropics: the effects of changing yield and technology. Environmental Research Letters 3.

Hanemaaijer, A., W. de Ridder, T. Aalbers, B. Eickhout, H. Hilderink, L. Hitman, T. Manders, D. Nagelhout, and A. Petersen. 2008. The Netherlands in a sustainable world. PBL Report 500084003, Netherlands Environmental Assessment Agency (PBL), Bilthoven, The Netherlands.

Hertel, T. 1997. Global trade analysis: modeling and applications. Cambridge University Press, Cambridge, UK.

Hertel, T., and R. Keeney. 2006. Assessing the impact of WTO reforms on world agricultural markets: a new approach. Pages 402-428 in A. Sarris and D. Hallam, editors. Agricultural commodity markets and trade: new approaches to analyzing market structure and instability. Edward Elgar Publishing, UK.

Himmel, M. E. 2007. Biomass recalcitrance: engineering plants and enzymes for biofuels production. Science 315:804-807.

IMAGE team. 2001. The IMAGE 2.2 implementation of the SRES scenarios. RIVM, Bilthoven, The Netherlands.

Klein Goldewijk, K., J. G. van Minnen, G. J. J. Kreileman, M. Vloedbeld, and R. Leemans. 1994. Simulating the carbon flux between the terrestrial environment and the atmosphere. Water, Air and Soil Pollution 76:199-230.

Klijn, J. A., L. A. E. Vullings, M. v. d. Berg, H. van Meijl, R. van Lammeren, T. van Rheenen, A. A. Tabeau, A. Veldkamp, P. H. Verburg, H. Westhoek, 
and B. Eickhout. 2005. The EURURALIS study: technical document. Alterra Report 1196. Wageningen, the Netherlands.

Lambin, E. F., B. L Turner, H. J. Geist, S. B. Agbola, A. Angelsen, J. W. Bruce, O. T. Coomes, R. Dirzo, G. Fischer, C. Folke, P. S. George, K. Homewood, J. Imbernon, R. Leemans, X. Li, E. F. Moran, M. Mortimore, P. S. Ramakrishnan, J. F. Richards, H. Skånes, W. Steffen, G. D. Stone, U. Svedin, T. A. Veldkamp, C. Vogel, and J. Xu. 2001. The causes of land-use and land-cover change: moving beyond the myths. Global Environmental Change 11:261269.

Leemans, R., B. Eickhout, B. Strengers, L. Bouwman, and M. Schaeffer. 2002. The consequences of uncertainties in land use, climate and vegetation responses on the terrestrial carbon. Science in China 45:126-141.

Matson, P. A., W. J. Parton, A. G. Power, and M. J. Swift. 1997. Agricultural intensification and ecosystem properties. Science 277:504-509.

Millennium Ecosystem Assessment. 2005. Ecosystems and human well-being: biodiversity synthesis. World Resources Institute, Washington, D.C., USA. [online] URL: http://www.maweb.org/docum ents/document.354.aspx.pdf.

Mittermeier, R. A., C. G. Mittermeier, T. M. Brooks, J. D. Pilgrim, W. R. Konstant, G. A. B. Da Fonseca, and C. Kormos. 2003. Wilderness and biodiversity conservation. Proceedings of the National Academy of Science 100:10309-10313.

Myers, N., R. A. Mittermeier, C. G. Mittermeier, G. A. B. Da Fonseca, and J. Kent. 2000. Biodiversity hotspots for conservation priorities. Nature 403:853-858.

Nakicenovic, N., editor. 2000. Special report on emission scenarios. Intergovernmental Panel on Climate Change (IPCC), Geneva, Switzerland.

Nellemann, C., M. MacDevette, T. Manders, B. Eickhout, B. Svihus, A. G. Prins, and B. P. Kaltenborn. 2009. The environmental food crisis. The environment's role in averting future food crises. A UNEP Rapid Response Assessment. UNEP, GRID-Arendal, Norway.
Netherlands Environmental Assessment Agency (MNP). 2006. Integrated modelling of global environmental change. An overview of IMAGE 2.4. A. F. Bouwman, T. Kram, and K. Klein Goldewijk, editors. Netherlands Environmental Assessment Agency, Bilthoven, The Netherlands. [online] URL: http://www.rivm.nl/bibliotheek/rapporten/50 0110002.pdf.

Netherlands Environmental Assessment Agency (PBL). 2010. Growing within limits. A report to the Global Assembly 2009 of the Club of Rome. PBL report 500201001, Netherlands Environmental Assessment Agency, Bilthoven, the Netherlands.

Nowicki, P., H. van Meijl, A. Knierim, M. Banse, J. Helming, P. Margraf, B. Matzdorf, R. Mnatsakanian, M. Reutter, I. Terluin, K. Overmars, D. Verhoog, C. Weeger, and H. Westhoek. 2006. Scenar 2020. Scenario study on agriculture and the rural world. European Commission, Brussels, Belgium. [online] URL: http://ec.europa.eu/agricul ture/agrista/2006/scenar2020/final report/scenar2020final. pdf.

Rienks, W. 2008. The future of rural Europe. An anthology based on the results of the Eururalis 2.0 scenario study. Wageningen UR and Netherlands Environmental Assessment Agency, Wageningen, The Netherlands. [online] URL: http://www.eurura lis.eu/current/background/documents/The\%20future\% 20of\%20rural\%20Europe.pdf.

Rotmans, J. 1990. IMAGE: an integrated model to assess the greenhouse effect. RIVM, Bilthoven, The Netherlands.

Schnepf, R. D., E. Dohlman, and C. Bolling. 2001. Agriculture in Brazil and Argentina: developments and prospects for major field crops. Economic Research Service, U.S. Department of Agriculture, Washington, D.C., USA.

Stehfest, E., G. B. Woltjer, A. G. Prins, B. Eickhout, and M. Banse. 2009. First and second generation biofuels up to 2030: possible scenarios and their environmental impacts. Paper presented at the AGSAP conference, 10-12 March 2009, Egmond aan Zee, The Netherlands. 
Taheripour, F., T. W. Hertel, W. E. Tyner, J. F. Beckman, and D. K. Birur. 2008. Biofuels and their by-products: global economic and environmental implications. Paper presented at the 11th Annual Conference on Global Economic Analysis, Helsinki, Finland. [online] URL: https://www.gtap. agecon.purdue.edu/resources/download/3974.pdf.

Van Meijl, H., T. van Rheenen, A. Tabeau, and B. Eickhout. 2006. The impact of different policy environments on landuse in Europe. Agriculture, Ecosystems and Environment 114:21-38.

Van Meijl, H., and F. W. Van Tongeren. 2002. The Agenda 2000 CAP reform, world prices and GATTWTO export constraints. European Review of Agricultural Economics 29(4):445-470.

Verburg, P. H., J. Ritsema van Eck, T. de Nijs, H. Visser, and K. de Jong. 2004. A method to analyse neighbourhood characteristics of land use patterns. Computers, Environment and Urban Systems 28 (6):667-690.

Verburg, P. H., W. Soepboer, A. Veldkamp, R. Limpiada, V. Espaldon, and S. S. A. Mastura. 2002. Modeling the spatial dynamics of regional land use: the CLUE-S model. Environmental Management 30 (3):391-405.

Verburg, P. H., H. van Meijl, and B. Eickhout. 2008. A multi-scale, multi-model approach for analyzing the future dynamics of European land use. The Annals of Regional Science 42(1):57-77.

Westhoek, H. J., M. Van den Berg, and J. A. Bakkes. 2006. Scenario development to explore the future of Europe's rural areas. Agriculture, Ecosystems and Environment 114:7-20.

Woltjer, G., M. Banse, H. van Meijl, and A. Tabeau. 2007. Alternative approaches to extend GTAP to biofuel crops. Paper presented at the 11th Annual Conference on Global Economic Analysis, Purdue University, West Lafayette, Indiana, USA. [online] URL: https://www.gtap.agecon.purdue.edu/resources/ download/3258.pdf. 